\title{
Development of Early Young Adults that have Autistic Characteristics
}

\author{
Tiersa Undap \\ Department of Special Education \\ Universitas Negeri Manado Tomohon, North Sulawesi, Indonesia \\ tiersa_bsb@yahoo.com
}

\begin{abstract}
The purpose of this study is to describe how the handling of parents of children with autism is seen from the attention of parents, knowledge of parents and assignments from parents to children. This study uses a qualitative phenomenological research method by looking at and observing the handling of parents and also the development of children with autism in early adulthood. The subject in this study was one of the early adult autistic people who did not go to school. In this study researchers used data collection techniques through observation and interviews. The observation made was participant observation and the researcher interviewed the subject's mother as a respondent. The results showed that parents' handling of children was quite good in terms of attention and assignment to train children's development in emotional aspects, social interaction as well as children's physical abilities. But in terms of parental knowledge is still lacking.
\end{abstract}

Keywords: early adult autism, youth development, parental management

\section{INTRODUCTION}

Children with special needs are children who have differences with children in general. Children with special needs (formerly referred to as extraordinary children) are defined as children who need special education and services to develop their full human potential (Hallahan and Kauffman, 2003). Children with special needs do not have the characteristics of psychological or physical development with the average age of his age. But despite being different, there are also children with special needs showing emotional, mental, or physical inability in the social environment.

There are several types of children with special needs that we often encounter, namely hearing impairment, visual impairment, physical impairment, mental retardation, mental retardation, autism, down syndrome, and mental retardation (mental deterioration). According to data from Unesco in 2011, there were 35 million people with autism worldwide. On average, 6 out of 1000 people in the world have autism. In the United States, autism is owned by 11 out of 1000 people. Whereas in Indonesia, the ratio is 8 out of every 1000 people. This number 2 is quite high considering that in 1989, only 2 people were known to have autism.

Autism is still a nightmare for most parents. Problems faced by parents who have autistic children include: when a child is diagnosed with autism, people are shocked, panicked, confused and feel guilty; feelings of shame and confusion to explain to others about the child's condition; cost issues for maintenance; controlling emotions in children and how to deal with children when children are tantrums; confused looking for a school that is suitable for children; and worry about the child's future (Nurhayati, 2003).

But there are also parents who accept the field of what God has given them, one of which is the parents of children with autism who are the subject of this study. Here, the parents of the subject are very familiar with the condition of their child but unfortunately due to lack of understanding of the importance of education for children with special needs, the child is not schooled until adulthood. Children with special needs who are the subject of this study are children with autistic characteristics based on the autistic child characteristics (Djiwo, 2005).

This subject has entered early adulthood, because it is not schooled the subject only learns from the subject's parents at home with a minimum education without any special knowledge in educating autistic children. Subjects have special skills such as being able to sew, plant, shape carved spheres from Styrofoam or wood, and really like something round. From the emotional side, when angry the subject cannot control whatever anger in front of him can be damaged except playing alone. When he is happy, he prefers watering flowers and planting fruit seeds in the front yard of the house.

The reason researchers take this subject is that researchers see developments in terms of being able to do things alone that are good enough and good emotional abilities as well. Already able to understand the intentions of others, though often times can be misunderstood with guidance and education from parents who have no understanding of autism themselves. This study will examine how the self-development of young adults who have autistic characteristics and especially those not educated by their parents.

\section{METHOD}

The research method used in this study is a qualitative method. Tylor (Moleong, 2007), defines 'qualitative methodology as a research procedure that produces descriptive data in the form of written or oral words from people and observable behavior'. This approach is directed at the background of the individual holistically (whole).

The design used in this study is the phenomenological research design. Phenomenology is a philosophy initiated by Edmund Husserl (1900/1970) in the early twentieth. One of the main objectives of phenomenology is to want to ground the foundations of knowledge radically so that skeptic attacks on rationality and procedures can be dealt with. 
The subjects in this study were one early adult autistic child who did not go to school and was looked after by biological parents who did not have basic knowledge about children with special needs. The author takes the subject of autism in early adulthood as a phenomenon to be examined due to emotional and physical maturity of the subject. The subject itself is not schooled by parents due to the lack of parental attention to the education of children with special needs. But on the other hand, the parents of the subject give special attention to the subject at home. This research is located in Buha Village, Mapanget District, Manado City, North Sulawesi. The author takes the subject of autism in early adulthood because the authors see the subject is one of several autistic children in the city of Manado. Data collection in this study used observation, and interviews.

\section{RESULTS}

In accordance with the results of observations and interviews that have been conducted. The author interprets the results of these observations and interviews.

\section{Youth Development is seen from several aspects}

a. Emotional development

Judging from observations, the subject's emotional development is good, laughter and anger are the emotions that the subject most often shows. When interviewed the parents said the development of emotions in the subject was quite normal, and emotions that were often shown by subjects were laughter and anger. Parents also explain when the subject is very difficult to temper anger.In accordance with the results of observations and interviews that have been conducted. The author interprets the results of these observations and interviews.

The development of emotions is very important for youth, when youth are able to show emotions according to their feelings it is already fairly good. Compared to other young men who have difficulty showing their emotions. The development of good emotions on the subject will make it easier for others to know the feelings the subject is feeling. And that makes communication between the subject and other people better.

\section{b. Social interactions}

Judging from observations, subject social interaction is very lacking. The subject is always inside the house, doing a lot of activities in the house so it rarely goes out with the surrounding community. The subject only interacts a lot with people in his house or people he already knows. When interviewed parents acknowledged the subject rarely interacted with the surrounding environment because the subject rarely left home. And the subject also does not have the same playmates with him.

Lack of subject interaction with others is the same as lack of communication from the subject. And lack of communication can reduce the sensitivity of the subject to others. The subject will be a non-responsive youth, lacking concern for others.

\section{c. Physical Ability}

Judging from observations, the physical ability of the subject is very good. The subject is able to do many activities like other normal people, the subject does some work every day such as watering plants. When interviewed the parents also said the subject had quite good physical abilities. The subject is a strong person and will be even stronger when he is angry. Parents also said there were many things the subject could do alone, some of which were lifting heavy weights, helping parents when told to, also watering plants in front of the house, the subject also often planted plants and it was proven he could take care of the weeds until they grew well.

Good physical ability on the subject makes the subject become an independent young man, able to use his physical needs and desires without the need for help from others.

\section{Handling of Parents}

Handling of parents to youth / subjects with autism problems is quite good, it can be seen from more attention and assignments to train the physical and cognitive youth, it's just that parents are still lacking in knowledge in this regard specifically about autism.

a. Parents attention

Judging from the observation that parents are giving more special attention to the subject than the siblings of the other subjects, whatever the wishes of the subject will always be obeyed. And when interviewed, parents said that they were very concerned about the subject, starting from often inviting the subject to tell stories, following the subject's wishes, and meeting all their needs and some subject requests (related to toy items).

This attention is very good for the development of the subject in the future. Starting from the development of emotions and physical training of the subject. With the attention of parents and from other families the subject will not feel lonely even though basically the subject prefers to be alone. Attention from parents is also able to make youth / subjects feel at ease and calmer.

\section{b. Parental Knowledge}

Seen from the observation that parents do indeed look very ignorant / understand about autism. Parental knowledge is limited to how to educate normal youth. And when interviewed parents acknowledge that they still lack understanding of what parents can and should not do with their autistic youth, parents also often do not understand / do not understand what the subject is talking about.

Parental knowledge especially for autistic youth is very important. The ways of caring for autistic youth are different from other normal youth. There are some foods like chocolate and yeast so should not be consumed by autistic youth. This will make young people angry and impatient. If such things are not known by parents, it will be difficult for parents themselves to care for and raise autistic youth. That is why early knowledge for parents who have autistic youth is very important.

\section{c. Giving assignments / roles to youth from parents}

Judging from observations, the subject is often given a task by parents, the subject is not just silent. The subject does many things at home. And when interviewed parents admit often giving tasks to the subject so that the subject is not bored when in the house. Among them the task of washing dishes, watering flowers and drying clothes. This is very good for the subject itself. With the given task or 
job, it will train the subject. Train the subject's physical and cognitive abilities simultaneously. The subject will think about how to complete the work that has been given well without making mistakes.

\section{DISCUSSION}

In the study of early adult youth self-development which has autistic characteristics seen from several aspects, namely regarding the handling of parents which includes attention, knowledge of parents and also assigning tasks / roles to youth and about youth development which includes emotional development, social interaction as well physical development of autistic youth. Will be discussed by the authors below.

Based on the concept of Monks (1999), development is a process towards perfection that cannot be repeated again. Development is defined as a change that is permanent and cannot be returned. For example, physical development, changes in physiological form and function will change since young people and continue to grow toward becoming an adult human.

The development of the subject's emotions is good enough, the subject can show emotions according to the circumstances. The subject will be angry when something happens that is not as expected. And the subject will laugh happily when there is something to be liked by him. By showing emotions as well as expressions from the subject, the subject's communication with other people will be a little easier. Because with emotions people can understand a little about the purpose of the subject even though the words of the subject are still difficult for others to understand. Social interaction

Based on Thibaut and Kelley's concept that social interactions as events influence one another when two or more people are present together, they create an outcome with each other or communicate with each other. So, in the case of interactions, each person's actions aim to influence other individuals.

In terms of social interaction seen that the subject is not very good, the subject does not have a playmate who is like the subject so to communicate with strangers the subject is still very rigid and unfamiliar. Subject interaction is only dominant in the house because most of the subject's activities occur at home. And it appears that the subject does not like to play outside the home.

Lack of interaction from the subject adversely affects the psychological development of the subject. The subject's empathy for others will decrease or it may even be no longer empathy. In the interview, the subject's mother said there was a factor that supported the communication of the subject, which was found in the play of the subject. For example, for now the subject is very fond of the ball and parents always buy the ball with different sizes, it makes the subject feel happy and the subject will be happy to also communicate with other people. So subject communication depends on the subject's happy feelings.

In terms of social interaction seen that the subject is not very good, the subject does not have a playmate who is like the subject so to communicate with strangers the subject is still very rigid and unfamiliar. Subject interaction is only dominant in the house because most of the subject's activities occur at home. And it appears that the subject does not like to play outside the home.

Lack of interaction from the subject adversely affects the psychological development of the subject. The subject's empathy for others will decrease or it may even be no longer empathy. In the interview, the subject's mother said there was a factor that supported the communication of the subject, which was found in the play of the subject. For example, for now the subject is very fond of the ball and parents always buy the ball with different sizes, it makes the subject feel happy and the subject will be happy to also communicate with other people. So subject communication depends on the subject's happy feelings.

\section{CONCLUSION}

From the results of observations and interviews, it can be concluded that the phenomenon of autism in early adult youth by looking at several aspects as follows:

\section{Development of Autistic Children}

The development of the subject's emotions was quite good. Seen from several emotions that the subject shows and in accordance with the state of the subject at that time. There are no artificial emotions. The subject will be angry at things that happen and not in accordance with their wishes and the subject will laugh at things that the subject likes.

Lack of interaction with the surrounding environment makes the subject always do not care about what is happening around him. The subject only cares about what is happening in his own world, with his game and also his favorite items. He will be more emotional when he sees his favorite items damaged than seeing other things outside his world.

The physical development of the subject looks very good, the subject is able to do many things alone without help from others. The physicality of the subject is quite strong, and when the subject is angry and raging it is very difficult for others to calm him down because the power that is in the subject is often stronger than other normal people.

\section{Handling of Parents}

Parent's attention to children is very important for children's growth and development, especially in subjects who have autism. Attention from parents or people closest to the subject greatly influences many things in the subject. The subject is different from other children and for attention must also be distinguished.

In terms of educating parents should have sufficient knowledge and knowledge. Especially if you have children with special needs that must be given special education as well. Parents should be able to know from the beginning of the subject was born, the symptoms that occur in the subject and the problems that the subject experienced during growth. From there parents must begin to learn it so that in the future children can grow and develop properly.

The assignment of tasks is very important to familiarize the subject to become an independent child despite its various shortcomings. Parents show that by giving assignments to the subject, the tasks will automatically be carried out by the subject without 
instructions from the parents anymore. For example, planting and caring for the planted has become a daily job for the subject. And that is due to giving assignments by parents.

\section{REFERENCES}

[1] Budiman. 1998. Tatalaksana Terpadu Pada Autis Simposium Tatalaksana Autis, Gangguan Perkembangan Pada Anak. Jakarta

[2] Chaplin, J. P. 2006. Kamus Lengkap Psikologi (Penerjemah: Kartini Kartono)Jakarta: PT Raja Grafin

[3] Dayakisni, T. 2003. Psikologi Sosial. Universitas Muhammadiyah Malang: Malang

[4] Desmita. 2007. Psikologi Perkembangan. Bandung: PT Remaja Rosdakaya

[5] Dosenpsikologi. 2017. Teori Perkembangan Anak Menurut Para Ahli. Dosenpsikologi.com. 27 Juni 2017

[6] Hadis, Abdul. 2006. Pendidikan Anak Berkebutuhan Khusus Autistik Cetakan Pertama. Bandung: Alfabeta

[7] Hasdiana. 2013. Autis Pada Anak Pencegahan, Perawatan, dan Pengobatan. Yogyakarta: Nuha Medika.

[8] Ibeng, P. 2018. Pengertian Sosial Dan Unsur Menurut Para Ahli Pendidikan. Yogyakarta: Media.
[9] Mulyana, D. 2004. Metodologi Penelitian Kualitatif. Bandung: PT Remaja Rosdakarya.

[10] Moleong, L. J. 2007. Metodologi Penelitian Kualitatif Bandung: PT Remaja Rosdakarya.

[11] Muhammad, J. 2008. Special Education For Special Children: Panduan Pendidikan Khusus Anak-anak dengan Keturunan dan Learning Disabilities. Bandung: Mizan Media Utama.

[12] Novianto. 2014. Latar Belakang Anak Berkebutuhan Khusus. Surakarta: UMS.

[13] Sugiyono. 2012. Metode Penelitian Pendidikan Pendekatan Kuantitatif, Kualitatif, dan $R \& D$. Bandung: Alfabeta

[14] Sugiyono. 2012. Memahami Penelitian Kualitatif. Bandung: Alfabeta.

[15] Sugihartono. 2007. Psikologi Pendidikan. Yogyakarta: UNY Press.

[16] Suhartini. 2000. “Anak Autis" Manifestasi Klinis Penyebab dan Pendektesiannya. Paper presented Seminar Deteksi dan Intervensi Dini Autis Pusat Pengkajian dan Pengamatan Tumbuh Kembang Anak Penaleluasa AMSA, FK UGM, Yoyakarta.

[17] Sminth, J. 2009. Psikologi Kualitatif Panduan Praktis Metode Riset. Yogyakarta: Pustaka Belajar. 